\title{
Plants Used in Ethnoveterinary Medicine in Cows. A Review
}

\author{
Cristina EL MAHDY ${ }^{1}$, Silvana POPESCU ${ }^{2 *}$ Cristin BORDA ${ }^{2}$ and Anamaria BLAGA PETREAN ${ }^{2}$ \\ ${ }^{1}$ Department of Fundamental Sciences, University of Agricultural Sciences and Veterinary Medicine, Cluj - \\ Napoca, Romania \\ ${ }^{2}$ Department II Animal Production and Food Safety, University of Agricultural Sciences and Veterinary \\ Medicine, Cluj-Napoca, Romania \\ *corresponding author: silvana.popescu@usamvcluj.ro
}

Bulletin UASVM Animal Science and Biotechnologies 76(2)/ 2019

Print ISSN 1843-5262; Electronic ISSN 1843-536X

DOI:10.15835/buasvmcn-asb: 0012.19

\begin{abstract}
Through the regulations CE.834/2007 and implementing rules CE 889/2008, regarding the organic production the treatment with antibiotics in livestock are extremely limited. Therefore plants can replace medicines in treatment of certain conditions. The plants used in ethnoveterinary medicine are varied depending on area, but this review refers to plants existing in Romania identical to those existing in other areas of the world, some being used only in certain areas, others in areal extended, but it can be a start for farmers to seek natural remedies. There are 66 plant species which belong to a large number of families, but most plants belong to the family Asteraceae (11 -16.66\%), followed by species of family Solanaceae (6.06\%) and family: Malvaceae, Adoxaceae, Convolvulacea, Euphorbiaceae, Fabaceae with 3 species each (4.54\%). Of the plants, 11 species (16.8\%) are considered to be toxic and $18(27.2 \%)$ potentially toxic but, have therapeutic effect in extremely small amounts. Regardless of the area, plants are used in the same treatments in different form.
\end{abstract}

Keywords: Cows, ethnoveterinary, plants, treatment

\section{Introduction}

SriBalaji and Chakravarthi in a paper published in 2010, claim that the treatment of animals began with their domestication, ethnoveterinary knowledge having for purpose, maintaining healthy animals. The first documents dates with 2000 - 1800 years B.C, when the ancient indians realized the benefits brought by healthy animals (Kohli, 2015). With 1800 years before Christ, King Hamurabi of Babylon introduced a veterinary law, through which, were perceived, fees and charges for treatment of cows and donkeys (Selvaraju et al., 2011).

With a tradition of over 5,000 years, India, is the country with the most sophisticated medical culture, farmers, using their knowledge in animal treatment until nowadays (Mooventhan et al., 2016).

Verma and Sing (2008), remember that, in ancient literature of India, there were over 500 plants that had medicinal uses and 800 used as remedies in indigenous systems of medicine.

Many knowledge about plant treatment has been lost with modern therapy (Selvaraju et al., 2011), but, in developing country, often, the lack of medication and treatment of animals is precarious, therefore, etnoveterinary medicine that is concerned with traditional care through the knowledge, skills, methods, practices and beliefs of animal health care, is the alternative (Moreki et al., 2012). 
After Wedson et al., (2012), the main constraint in production increasing is related by the precarious animal health, which is why the promotion of ethnoveterinary medicine can be an economically efficient alternative (Krishna, et al., 2005). Along with methods of care, healing and management of livestock, ethnoveterinary practice also take into account social practices, the way of integrating animals in farming system (Wanzala et al., 2005).

In Europe, ethnoveterinary practices are quite rare, modern medicine taking the place of traditional practices, but these, have been preserved in the rural areas of the Mediterranean basin (González et al., 2011). After Mayer et al. (2017), the knowledge and application of etnoveterinary medicine is applied in 12 of the 37 countries of the European Community, but, between these countries there are quite remarkable differences (Romania, Spain, Italy and Albania). Similarities were found between ethnoveterinary medicine applied in Swiss and Italy, but the most investigated areas were those belonging to Italy, Spain and Turkey.

In ethnoveterinary medicine, parts of plants such as root, bark, stem, leaves, flowers, seeds are used in the form of infusion, decoction, ointment, powder, drops (Schmid et al., 2012).

Sometimes the beneficial action comes from the plants considered toxic, which contain saponins, terpenoids, phenolic compounds, alkaloids, carotenoids, the effects of their administration being: antioxidant, anthelmintic, fight against metabolic disorders but, at the same time may have hepatotoxic, neurotoxic effect (Poutaraud et al., 2017).

Although not all saponins have the same effects, are used in ethnoveterinary medicine due to biological effects: antibacterial, antifungal, antiviral, anti-inflammatory, anti-edemic, analgesic, antitussive and expectorant. The tannin of the plant by its pharmacological effects: astringent, antibacterial, antifungal, mucoprotective, antioxidant and enzyme inhibiting, is used to treat diarrhea, burns, but also in placental retention in cows (van der Merwe et al., 2010).

The plants, some of them with toxic potential, present in spontaneous flora whose area of spreading is wide: Italy, Greece, Turkey, Romania: Chelidonium majus L., Malva sylvestris L., Mentha pulegium L., Sambucus nigra L., Thymus vulgaris $L$., can be administered as decoction, ointment, in treatment of certain disordes and injuries in cows (Quave et al., 2012).

\section{Aim of the study}

The aim of the paper was those to identify the species of plants which exists on the pastures, meadows from Romanian territory similar to those from other countries of the European community and parts of the world, which are or, can be used in ethnoveterinary treatments in cows by farmers especially those who are registered in the organic farming system and not only.

\section{Plants used in ethnoveterinary medicine with multiple action in cow}

The content in organic acids, resins and tannin of Malva sylvestris L. (mallow) indicates it as good natural remedy applied in case of wounds, abdominal pain, bloating, sprains, pneumonia, poisoning, administered as appropriate, in form of decoction (per os) or external application (Bullitta et al., 2007).

A beautiful and feared plant, Aconitum napellus $L$ (queen of poisons), it is used in ethnoveterinary medicine in diseases such as: transport fever, acute changes, stress caused by castration, manipulation, weaning of animals (McCrory, 2012).

Castor bean (Ricinus communis L.) seeds contain about 50\% oil, ricinin (alkaloid) and ricin, a very toxic glycoprotein, but, which at low doses has utility in treatment of constipation, dermatophilia, placental retention, or wound healing (Fitsum and Mekonnen, 2017).

Equisetum arvense (horsetail) is used during calving period to maintain the mineral balance (www.bionaturesanteanimale.fr).

After Davidović et al., (2012) has immunostimulatory action and, curatively, serves as remedy in gastrointestinal disorders. The whole plant can be used to treat urinary problems (Viegi et al., 2003).

Decoction of bark, flowers, adult fruits of viburnum (Viburnum spp.), has a wide range of uses: astringent, homeostatic, antispastic, diuretic, tonic. In cows, decoction obtained from flowers is used in cases of coughing, treating gastrointestinal diseases or as astringent against diarrheal episodes. In calves, decoction from fruits (1:20) has vitaminic, tonic, diaphoretic effect (1-2 
spoon/day, given 3-4 days, consecutively), while, decoction obtained from bark (1:10) is used to relax the intestinal muscles 3 times/day (www. sadovod-ogorodnik.ru).

In case of oliguria, farmers can administer to cows, Cynodon dactylon (Bermuda grass) in the form of fodder or paste. The paste is made by grinding the plant, mixed with water, which is applied to the pelvic area (Masood et al., 2015). Giving the whole plant of Cynodon dactylon (Bermuda grass), acts as anthelmintic or favors treatment against mastitis; rhizomes are used in cases of internal lesions and juice in cases of hematuria (Venkata et al., 2016).

The aerial parts of bermuda grass in amount of $0.3 \mathrm{~kg} /$ day are administered as feed for for increasing milk production and milk quality. The leaves are used to treat conjunctivitis by grinding them and using a teaspoon of juice obtained as drops in each eye in the morning for 3 days (Verma, 2014). The whole freshly crushed plant and transformed into a paste is applied externally on wounds for 2-3 days until healing (Nagayya et al., 2017).

Table no. 1 represents the systematic form of the paper.

Plants used in ethnoveterinary medicine with healing effect of injured skin in cows

From plants with antiseptic and antiinflammatory action used in wound healing and formation of granular tissue, accelerating epithelization of wounds, Davidović et al.(2012), remember: yarrow (Achillea millefolium L.), or, marigold (Calendula officinalis).

From the category of plants with cicatrisation effect, Lans et al. (2007) remember: Arnica spp. (arnica), Capsella bursa-pastoris (shepherd's purse), Lavandula officinalis (lavender), comfrey (Symphytum officinale L.).

Arnica montana (arnica) is the plant used for hundreds of years, due to its therapeutic effects in case of physical trauma at skin level: cuts, scratches, bruises, bites, luxation, sprains, but also use against fever caused by the onset of a cold, heart/circulatory, respiratory tract disorders (Chlodwig, 2015).

Marigold (Calendula officinalis) is considered beneficial in many skin disorders, cuts or purulent wounds, but, it has to be used only after the threat of infection has passed. It is not recommended to treat deep wounds because, marigold can seal the wound too quickly and does not allow drainage (www.sadovod-ogorodnik.ru).

Comfrey (Symphytum officinale L.) leaves and stinging nettle (Urtica dioica L.), have wound healing action, provided that, their use to be done only after the infecting action has been overcome. The bright skin of the animals is another benefit bring by these plants, which also have an antipruritus and disinfecting action (Laudo and Capasso, 2013).

Achillea millefolium (yarrow) leaves mixed with olive oil, beeswax, egg yolk and tallow, are the ingredients used to prepare an ointment at low fire which are apply locally on withers wounds caused by limiters (Uncini Mangenelli et al., 2001).

Excessive consumption of Symphytum officinale L. (comfrey) causes serious intoxication manifested by: hepatic toxicity and failure, liver cancer (Tikofsky, 2013). However, it is commonly used as cataplasm in the treatment of abscesses, wounds, acute mastitis, lesions of the udder, edema at the same level or, ketosis treatment (Lans et al., 2007).

The aerial parts of St John's-wort plant (Hypericum perforatum L.), boiled in water and administered in drinking water, are used in case of bloating, inflammation and swelling (Jarić et al., 2007).

Externally, chamomile (Matricaria chamomilla) tea, has healing effect on ulcers, abscesses, mouth mucosa inflamation or udder inflammation (www.sadovod-ogorodnik.ru).

Castor bean (Ricinus communis L.) seeds crushe to extracting the oil, has role in treating wounds by applying a few drops to the wound (Zia-Ud-Din et al., 2010). Powder obtained from castor bean leaves, rubbed on the skin of the animals twice a day also help to wounds healing (Zia-Ud-Din et al., 2010). Powder obtained from castor bean leaves, rubbed on the skin of the animals twice a day also help to wounds healing (Malla and Chhetri, 2012).

By bioactive compounds: ascorbic acid, alkaloids, glucosides, mucilages, essential oils, tannin, which eldeberry leaves contain them are used to treat wounds, infected nails,by applying crushed leaves on affected areas (Bullitta et al., 2007).

Viegi and Ghedira (2014) states that, administration of decoction obtained from aerial parts of black eldeberry it is used in udder inflammation after calving, and dried eldeberry 
flowers heated in olive oil are used to treat wounds and inflammation. By applying the bark as ointment, the effect is that of healing. As ointment, eldeberry leaves mixed with Scotch broom (Cytisus scoparius) and Blue Hound's-tongue (Cynoglossum creticum) in addition with olive oil and beeswax, is applied locally, to cure withers inflammation (Uncini Mangenelli et al., 2001).

Chenopodium album (lamb's quarters), considered weed frequently, helps to wound healing in cows, the whole plant being transformed into a paste which is given on the skin only for one day (Akash et al., 2014).

As external use, Chelidonium majus (greater celandine) treat various skin problems or lesions at this level. The same use is attributed to Conium maculatum (hemlock), for treating various skin problems; wounds, abscesses (Viegi et al., 2003).

A more tenacious plant, more resistant to drought and heat, such as tansy (Tanacetum vulgare), is hard to find (www.romedic.ro/), but it also finds use in treating wounds, ulcers (Waller et al., 2001).

Tea root of gentian willow (Gentiana asclepiadea L.), is used to treat inflammation and pain relieve. Farmers from Covasna (Transilvania) use the plant to treat digestive disorders in cows mixed with milk and, in mixture with clay or salt and water, is used externally in treatment of mastitis (Bartha et al., 2015). Roots of marsh mallow (Althaea officinalis) under decoction form, applied like compresses on swollen withers have anti-inflammatory effect (Uncini Mangenelli et al., 2001).

Juice obtained from squeezing of black mulberry fruits (Morus Nigra L.) administered in water per os has curative effect on infected skin (Akash et al., 2016). Also, the juice results by grinding peach tree (Prunus persica) leaves is applied on wounds or in case of eye problems, under drop form (Luseba and Tshisikhawe, 2013).

Under paste form, in India, the leaves of ivy (Hedera helix) are applied in area bitten by snake. In Lucania (Italy), Senecio vulgaris (ragwort) has the same use, namely: wound care caused by the snake bite (Viegi and Ghedira, 2014). Crushing the leaves of tobacco, soaking overnight, and oral administration is practiced in case of snake bite or fattening of cows (Yared et al., 2014).

To prevent wound infection caused by wolf bite, in cows, the rhizome of Veratrum album
L (white hellebore) in form of compresses is applied to the bite area. Juice obtained by crushing Sambucus ebulus (dwarf elder) leaves is applied directly to the place of snake bite or bee sting and, due to its anti-inflammatory action, the root and leaves of this tree are used to treat burned areas, inflammations, edema, eczema and urticaria (Davidović et al., 2012).

For eczema treatment, Al Mamun et al. (2015), describes the ingredients of the preparation used: approximately $58 \mathrm{~g}$ of Nicotiana tabacum leaves, will be soaked in $150 \mathrm{ml}$ cold water and stored overnight. The next day, the water is filtered, then boiled to obtain a concentrated solution, and after cooling, is added $30 \mathrm{ml}$ of rapeseed oil (Brassica napus). The mixture is applied several times on affected areas until healing.

\section{Plants with anti-parasitic and anthelmintic action in cows}

A widespread use in ethno-veterinary treatments is attributed to Urtica dioica (stinging nettle) due to thenumerous bioactive compounds: formic acid, mucilages, tannins, vitamins (Bullitta et al., 2007). Crushing seeds of Urtica dioica can be used to eliminate endoparasites (Laudo and Capasso, 2013).

The properties of Calendula officinalis (marigold) claim it as an excellent antiparasitic and repellent (Viegi et al., 2003).

In fight with external parasites, white lupine (Lupinus albus), can be applied as such, directly on the skin of animals or with the water resulting from boiling the seeds (Tikofsky, 2013), which due to their high content in alkaloids give a bitter taste to the skin (Bischoff et al., 2016). On crops, the effect is repellent and aficid (Mayer et al, 2014).

Decoction, made from lupine mixed with bean beans (Phaseolus vulgaris), stimulates milk secretion in cows, so it also has galactophore action (Di Sanzo et al., 2013).

Leaves of black and white wormwood (Artemisia vulgaris), have been used for centuries as anthelmintic in fight against oval and cylindrical worms, such as: Moniezia spp, nematodes: Ascaris spp., but also in treatment of animals infected with blood parasites (Trypanosoma, Plasmodium spp.) (Severino and Ambrosio, 2012).

In some areas of Italy mixture of wormwood, garlic and lard is given at cows, having vermifug action (Uncini Mangenelli et al., 2001). Fresh leaves mixed with lard, applied to the skin of 
bovines, has repellent action on flies (Quave et al., 2012).

Nicotiana tabacum L.(tobacco), is the plant used and reported to have anthelmintic activity in many parts of the world (Gakuya et al., 2011), the leaves being administered as such (Suroowan et al., 2017), or, as nicotine sulfate form, extracted from Nicotiana tabacum, and used to eliminate gastrointestinal nematodes: Monezia, Ascaridia, as well as other parasites (Laudo and Capasso, 2013).

Decoction obtained from tobacco leaves is applied directly to the skin of animals (Naik et al., 2017), which has external anti-parasitic role (Bischoff et al., 2016). The juice obtained from grinding of fresh tobacco leaves, applied on the whole animal body twice a day for one week eliminates calves tick infestations (Sharma et al., 2012).

Using 30 grams of Nicotiana tabacum leaves under powder form, applied locally on affected area and covered with clay is a remedy described in case of the myiazis (Farrah, 2009).

Tansy (Tanacetum vulgare), alongside other plants such as: wormwood (Artemisia spp.) or chicory (Cichorium intybus), due to their properties, are also used as anthelmintics (Waller et al., 2001). By secondary bioactive compounds, terpenoids and phenolic compounds, chicory (Cichorium intybus) can be used as feed for cows in order to eliminate Ostertargia ostertargia (AboEl-Sooud, 2018).

Stem and seeds of Cuscuta reflexa (giant dodder) transformed into a paste is applied to the cow's skin and buffalos for ectoparasites removal (Akash et al., 2016)

Dried roots of Veratrum album (white hellebore) applied to the skin or cooked in combination with sap extracting from leaves of Brassica oleracea (cabbage), are used in fight against lice in large and small ruminants (Gub, 2005). Locally, decoction of white hellebore leaves and roots can be used in the treatment against mites which causes scabies (Di Sanzo et al., 2013).

A plant considered to be toxic, Chelidonium majus (greater celandine), is also involved in ethnoverinary treatments. Applying fresh leaves of greater celandine or in powder form obtained from drying them, are beneficial in combating scabies in animals, or may have anthelmintic action administered as decoction (Blanco et al., 1999).
Queen of poisons (Aconitum spp.) have antiparasitic and repellent action, after Viegi et al., (2003).

Leaves of Datura stramonium (thorn apple) under decoction form can be applied externally as antiparasitic, repellent treatment (Pragada et al., 2012).

Aerial part of Juniperus communis L (juniper) can be applied in the treatment of skin diseases and fight against infestation with ectoparasites, while, the branches, in elimination of endoparasites and liverworms (Lans et al., 2007).

Consumption of Juglans nigra (black walnut), is poisoning for animals, which exhibit symptoms like: seizures, respiratory failure and laminitis, but, nutshell, can be used in therapy against intestinal parasites and to combat diarrhea (Tikofsky, 2013).

The infusion of branches, leaves and flowers of Manna Ash, (Fraxinus ornus), it is used in Italy to combat ectoparasitic infestation and to counteract diarrhea (Mayer, 2014).

\section{Plants used in ethnoveterinary medicine to treat digestive disorders in cows}

Plants containing heleborin, gentian, bitter substances, are used to stimulate saliva secretion and provide the optimal buffering capacity of ruminal fluid to prevent acidosis (Rikilt et al., 2011).

In treatment of digestive disorders, salicin from Salix alba L.; essential oils from flaxseeds (Linum usitatissimum) or common mallow (Malva sylvestris L.) have curative effects (Viegi et al., 2003). Decoction obtained from fresh leaves of Salix alba L. restores the rumination function.

It can be prepared in mixture with water but also with wine by boiling willow branches with addition of caraway flowers (Carum Carvi L) for 1 hour and administered as such (Uncini Mangenelli et al., 2001).

The tannin was, is and will be used traditionally against diarrhea episodes, reducing bleeding and congestion (Stevens, 2003).

The water obtained after 12 hours of maceration of the mixture of eldeberry (Sambucus spp.) and Manna Ash (Fraxinus ornus) bark, is used to treat gastrointestinal inflammation (Uncini Mangenelli et al., 2001). Sambucus nigra L. (black elderberry), has a lot of uses, especially the flowers, but neither the other parts are not forgotten by ethnoveterinary medicine. Black elderberry juice obtained from the infructescenses, administered 
to cows, is a promoter of growth (Matchett, www. sapork.biz), and curative, black elderberry, can be effective in gastrointestinal disorders treatment such as: colic, impaired digestion, tympanism and meteorism. In order to eliminate the meteorism, dried flowers of eldeberry are administered directly in feed or, under infusion form (Mayer et al., 2014)

Flowers of black elderberry are used as a diuretic administrated as decoction; flavonoids in flowers are recognized for the effect of improving immune function, especially in combination with vitamin C (González et al., 2011).

The "wild brother", Sambucus ebulus (dwarf elder) is administered to cows as purgative (Di Sanzo et al., 2013). Eldeberry root in form of decoct has purgative action, but is used in the same form in treatment of colds in cows (Viegi and Ghedira, 2014).

Marigold (Calendula officinalis) flowers, have bactericidal action in fight against staphylococci and streptococci, relax the smooth muscles of gastrointestinal tract, tonify the liver function, stimulate secretory activity, have choleratic effect, used as a treatment for gastritis, gastric ulcer and duodenal ulcer, colitis, enterocolitis. As cholagogue, marigold tincture $(1: 10 / 70 \%$ alcohol) can be administered to calves three times/day, diluted before use: 1 teaspoon per cup of water or milk (www.sadovod-ogorodnik.ru).

Due to the compounds present in the flowers of Matricaria chamomilla (chamomile), essential oils and flavonoids, this is the plant used to treat digestive disorders and abdominal pain in decoction or infusion form (Mayer et al., 2014). The dried chamomile flowers induce changes in bacterial morphology on Bacillus cereus and Staphylococcus aureus (Abo-El-Sooud (2018).

Chamomile, through its disinfecting, choleretic, anti-inflammatory and diaphoretic actions, inhibits fermentation processes in the gut (Bartha et al., 2015). In veterinary practice, chamomile tincture $(1: 10)$ is used to treat dyspepsia at calves (1 cup infusion 3-4 times a day one hour before consuming colostrum) (www. sadovod-ogorodnik.ru).

Astringent and antimicrobial properties make by Hypericum perforatum L (St. John's wort) a plant feared against stomach, intestinal, bladder inflammation, which, which in the form of infusion or decoction, encourages tissue repair.
Through its properties, it stimulates the secretion of digestive glands by promoting digestion and better absorption of nutrients (www.sadovodogorodnik.ru).

Aerial parts of Hypericum perforatum L contain substances that can produce photodermatosis called hypericism under direct influence of solar radiation. Therefore, animals receiving homeopathic treatment based on St John's wort will be kept in shade (Bourke and White, 2004).

Common wormwood or green ginger (Artemisia absinthium L.) helps in treatment of gastrointestinal disorders such as: colic, digestive disorders, tympanism and meteorism (Mayer, 2014).

It is true that, the ingestion of large quantities of Artemisia spp (wormwood) can cause digestive disorders, hallucinations, delirium, paralysis, and even death, or, change the taste of milk, but, aerial parts of plant mixed with feed or as decoction are used to counteraction diarrhea or loss of appetite. The plant is used to stimulate diminished secretion of digestive enzymes, disorders of bile secretion, but also for strengthening the organism (Bischoff et al., 2016). The aerial parts of wormwood, without root, administrated as infusion helps the calves to digest milk more easily, and decoction is used in treating diarrhea to this category of age (Davidović et al., 2012).

The treatment of diarrhea episodes in adult ruminants can be countered, administering the decoction obtained from mixture of aerial parts of Artemia absintum and evergreen oak (Quercus ilex) bark (González et al., 2011).

Flaxseeds (Linum Usitatissimum L.), are used to relieves spasmodic manifestations or convulsions by administering $500 \mathrm{ml}$ of flaxseed oil mixed with $28 \mathrm{ml}$ of turpentine and administered orally at the onset of symptoms. To eliminate the symptoms of flatulence, $300 \mathrm{ml}$ oil obtained from flaxseeds is mixed with $400 \mathrm{ml}$ of turpentine oil and given orally 2-3 times at 2 hours (Al Mamun et al., 2015).

The roots of marsh mallow (Althaea officinalis), are used in treatment of digestive and urinary disorders, chronic cough. Mallow has often been considered a functional gastrointestinal agent for ruminants (Quave et al., 2012). Leaves and aerial parts administered per os are considered useful in treatment of various digestive disorders such as: abdominal colic, tympanism, reactivation of 
rumination, diarrhea and constipation (Uncini Mangenelli et al., 2001).

The leaves of Malva sylvestris L. (mallow), in admixture with flaxseeds are administered for reactivation of the rumination in Tuscany (Italy); as decoction in meteorism treating, administered per os (González et al., 2011).

Tanacetum vulgare (tansy) contains in inflorescences, floral leafy parts and branches, volatile oils: tannacetone or $\beta$-thiona, cineol, 1-camphen, borneol, camphor, etc ; bitter substances, enolic ethers, flavonoids derived from luteolin, gumirezine, tanoids, malic acid, tartaric acid, tannacetamic acid, vitamin B1 (www. infuziedesanatate.ro/). The tincture obtained from tansy flower, intensifies intestinal peristalsis, increase the amount of gastric juice. Infusion from flowers, improves the secretory and motor function of gastrointestinal tract. Calves suffering from enterocolitis can be treated with infusion of tansy flowers: 6 grams $/ 200 \mathrm{ml}$ of water, divided into 3 administrations in warm form (www. sadovod-ogorodnik.ru).

Leaves grinded by Thymus vulgaris (thyme) and given in amount of 20 grams 2-3 times/day combats episodes of diarrhea, while stomach pain is treated with 50 grams of whole plant offered to animals once a day (Masood et al., 2015).

Caperspurge (Euphorbia lathyris) participate in amelioration of gastrointestinal disorders, being at the same time a repellent for mice (Viegi et al., 2003). Fruits have purgative effect and also it is used to suppress intestinal blockage. The fruits may be administered as decoct, or after cooking them in olive oil, and the oil obtained will be given per os. In calves, the ingestion of this plant can cause dysentery (Uncini Mangenelli et al., 2001).

The aerial parts of Chelidonium majus (greater celandine) mixed with feed are used to treat intestinal infections in cows, the leaves fight against bloating. Also, leaves of greater celandine, crushed and macerated have antidiarrheal effect (Vlková et al., 2015).

Mercurialis annua (annual mercury), can be used as purgative, although, plant use is not encouraged because of the toxic nature (Viegi et al., 2003). Uncini Mangenelli et al. (2001), received positive responses among farmers regarding the use of the whole plant as decoction, the water obtained being given to cows post partum to eliminate placenta, having at the same time laxative effect (Pieroni et al., 2004).

Another plant with potentially toxic character Melilotus albus (white melilot) due to the coumarin content with anticoagulant effect which acts as antivitamin K (Stegelmeier, 2018), is used as a remedy in treating stomach and indigestion problems, one palmul from whole plant being given by 3 time/1 day, maintains vigor (Kumari et al., 2009).

The tympanism, can be remedied administering to ruminants Colchicum autumnale (Autumn crocus) (Macleod, 1981), and as external use, fight against ectoparasites (Viegi et al., 2003).

The leaves of black nightshade (Solanum nigrum) administered orally reduces manifestations of gastrointestinal disorders in cows (Suroowan et al., 2017). And for the same purpose, decoction of leaves $(100 \mathrm{ml})$ is given once a day for 10 days (Pragada et al., 2012).

For gastritis treatment, the leaves, plays the role of "magician” (Venkata et al., 2016). Decoction obtained from fruits has purgative effect (Gwalwanshi and Bishwas, 2017), and decoction of fruit and leaves of Solanum nigrum administered orally is cure used in fever treating. The flatulence in cows can be treated with whole plant transformed into a paste and mixed with $500 \mathrm{ml}$ goat milk. From this extract, $50 \mathrm{ml}$ per os is administered, three times a day for 5-6 days (Taranisen and Nirlipta, 2016).

Administration of Aconitum (queen of poisons) can eliminate nervous signs and calm animals in cases of ketosis, when it is given in early stage (Macleod, 1981).

Within 6 weeks - 2 months after calving, in cows, may occur (ketosis). Datura stramonium (thornapple, jimsonweed) is administered to control seizures (Macleod, 1981).

Other uses of juice obtained from thornapple fresh fruit, although they are toxic, small amounts are administered to cows for cures cough, cold and pneumonia. Dried fruits can also be used for these diseases (Dilpreet et al., 2015).

Roots of Veratrum album L., are used as tea in treatment of diarrhea in calves (Bartha et al., 2015).

Rumex acetosella L (sheep sorrel) is used to reduce symptoms caused by gastrointestinal disorders (Viegi et al., 2003). Fruits of Rumex acetosella L. as well as those of Rumex obtusifolius 
L (bitter dock) are administered in case of diarrhea (Bartha et al.,2015).

Decoction of Rumex crispus (curly dock) leaves, given per os, has also antidiarrheal action (Uncini Mangenelli et al., 2001).

Other plants with anti-diarrhea effect: Plantago major, Calendula officinalis, Urtica dioica, Althaea officinalis, Anethum graveolens, Salix alba L. and Ulmus fulva (Lans et al, 2007).

Due to the tannin content, decoction made from evergreen oak (Quercus ilex), and sessile oak (Quercus petraea Matt) bark, administered orally is used against diarrheal episodes (Mayer, 2014, González et al., 2011, Bartha et al., 2015).

Decoction obtained from Fraxinus ornus (Manna Ash) bark and sometimes mixed with elderberry bark, left to soak whole night and then given to cows, can be helpful in the fight against gastrointestinal disorders and diarrhea. Fresh leaves are given to reactivate rumination, have antibacterial action and fight against colds (Uncini Mangenelli et al., 2001).

Fresh Amaranthus viridis (Green Amaranth), it is used as purgative in case of constipation in ethnoveterinary medicine (Shah et al., 2012).

Constipation can be counteracted by crushing the entire plant of Convolvulus arvensis (European bindweed) which, mixed with sugar, is administered per os for 4 days in cows (Akash et al., 2014).

The laxative effect of castor bean (Ricinus communis L) is due to ricinoleic acid released into the gut, by hydrolyzing castor oil. Stimulates intestinal secretion, promotes motility and decreases glucose uptake (van der Merwe et al., 2010)

Administration of $20 \mathrm{ml}$ of castor oil obtained from seeds, once a day for 5 days (Pragada et al. 2012, Suroowan et al., 2017) has the effect of counteracting constipation, and 50 grams of seeds administered as such for 7 days, has purgative effect (Verma, 2014).

Leaves and seeds of Silybum eburneum (milk thistle), are used to prevent ketosis, liver disease, giardia, and have a positive effect on critical growth phases. The plant given to the cows positively influences, the vitality, the productive performances, it has vitaminizing action and maintains the balance of the intestinal flora (www. bionaturesanteanimale.fr).
Fagopyrum esculentum (buckwheat) administered orally, has antimicrobial, bactericidal and diuretic action (Suroowan et al., 2017). It is the plant used as a cure for anemia in cows, administering an amount of about 250 grams grams of buckwheat leaves, twice a day for 5-7 days (Akash et al., 2014). It can be used even in treating liver problems in cows giving them the same amount of buckwheat leaves administered as feed 2 times a day for 3 consecutive days (Masood et al., 2015).

Urtica dioica, is used as galactogen stimulant (entire plant), the leaves of the plant as functional food (Di Sanzo et al., 2013). Consumption of the aerial parts, combats zinc deficiency or diarrhea (Lans et al., 2007), positively influences appetite, the growth, and, reduces stress (www. bionaturesanteanimale.fr); has antioxidant and antiviral activity (Celik and Tuluce, 2007). Leaves of Urtica dioica are recognized for their effect, anti- asthenic (Masood et al., 2015).

Natural calcium intake during calving can be obtained by administering this plant whose role is much more extended by maintaining the mineral balance of cows during the period of calving and lactation (www.bionaturesanteanimale.fr). It is used as a diuretic and antianemic, the plant being rich in iron (McGaw and Jacobus, 2010).

Plants with therapeutic effect in treatment of leg and foot-and-mouth disease in cows

Hyoscyamus niger (stinking nightshade), although, toxic plant, may have healing potential, applied externally in cases of lameness (Viegi et al., 2003), or, pain relief, given per os (Suroowan et al., 2017).

The magical effect of Plantago major (Broad leaf Plantain), are also found in ethnoveterinary medicine, the crushed vegetal material being applied at level of affected hooves until recovery but it is also used to treat oral cavity problems (Shah et al., 2012). The paste obtained from the leaves and mixed with water is used in toothache and injury. The decoction obtained from 2 bunch of leaves added in one liter of water eliminates the fever, giving $1 / 6$ parts of the decoction 3 times a day (Kumari et al., 2009).

Paste obtained from Cuscuta reflexa (giant dodder) applied externally twice daily is used in foot-and-mouth disease treatment (Malla and Chhetri, 2012). 
Nicotiana tabacum L.(tobacco) is used in footand-mouth disease treatment by leaves crushing and turning them into a paste mixed with sawdust and applied to the affected hooves (Lakshmi and Narasimharao, 2015, Venkata et al., 2016) or, leaves applied directly on hooves without any addition or, administered as feed (Akash et al., 2016).

The paste obtained from buckwheat seeds is applied externally in treatment of foot-and-mouth disease (Sharma et al., 2012).

Plants used for treatment of respiratory diseases and not only in cow

Although, a very poisonous plant, present in Romania, and other countries such as: Italy, Turkey, Serbia, Helleborus spp. (hellebore), has curative effect in treating respiratory conditions in cattle, by transcutaneous implantation procedure of a small part of root or branches (Maior, et al, 2013). In cows, raw root of Helleborus purpurascens is inserted into the ear to treat inflammation (Vlková et al., 2015); the petiole of Helleborus bocconei inserted into the ear or neck helps in treatment of bronchitis, and leaves of Helleborus foetidus are implanted in the ear for treatment of bronchitis and pneumonia (Bartha et al., 2015).

The rhizome implanted transcutaneously into the skin of salbe, has protective effect on animals in acute stages of some chronic diseases. Extract from rhizome or root of hellebore, may have immunostimulatory or immunodepression effect (Davidović et al., 2012).

Incision made in cows tail and insertion of small portion of root from Helleborus spp., plays antipyretic and antibacterial role in cases of pneumonia. Decoction obtained from leaves is given in case of cold and coughing in cows (Uncini Mangenelli et al., 2001). Hellerore, fight against bloating, tympanism and in combating warts (Davidović et al., 2012); but also against various external parasites: lice, fleas, by preparing and applying the powder obtained from rhizomes or root from white hellebore, and in form of tincture, hellebore struggles against Hypoderma bovis (www.sadovod-ogorodnik.ru/).

Fresh and crushed leaves of green hellebore or Helleborus odorus, are applied locally to treat purulent abscesses in withers area. It is recommended that, before the treatment to pierce the skin in order to eliminate the pus (Uncini Mangenelli et al., 2001).
Due to the bitter substances present in plant, Helleborus, stimulates production of saliva, ensures optimal buffering of ruminal fluid, which has like purpose preventing acidosis (Groot et al., 2001).

With all the benefits, due to its toxicity, the plant will be harvested by a true connoisseur and administered after obtaining the necessary information on the dangerous substances in the plant.

Juniperus communis L. (juniper), in admixture with urine and turpentine is used in Transylvania for treatment of respiratory diseases (Bartha et al., 2015).

Castor bean (Ricinus communis L) fight against hyperthermia in cows (Farrah, 2009). The castor bean leaves and strain administered in powder form, orally, for 3 consecutive days, have application in treatment of colds in cows (Akash et al., 2014).

\section{Plants used to treat cardiovascular and nervous disorders in cows}

Even if, Digitalis lanata (woolly foxglove) is considered to be a toxic plant due to its content in glycosides, saponins, digilanides A, B and C (El Mahdy et.al,.2017), leaves, root or seed used in extremely small amounts is helpful in heart disease. In addition, the leaves of Digitalis purpureea (common foxglove) are used in treatment of burned areas (Tikofsky, 2013).

For the same purpose, one palmful leaves of common foxglove fried in oil, can be used as an ointment (Kumari et al., 2009).

The beneficial action given by the convalotoxin content which may be toxic but also therapeutic from Convallaria majalis (lily of the valley) is used as alternative to Digitalis in cardiac failure treatments due to cardiotonic action (Laudo and Capasso, 2013), and as diuretic stimulant by using dry rhizome, known as the root of Convallaria, (http://poisonousplants.ansci.cornell.edu/, 2015).

Although extremely toxic plant, rich in high alkaloid content (Gaillard and Gilbert, 2001, Chaney, 2015), Gilotta and Brvar, 2010, Wink, 2009), Veratrum album (hellebore) has been used since the Middle Ages in Europe by cow farmers as emetic (Lans et al., 2007). In etnoveterinary medicine Veratrum album $\mathrm{L}$ is used to counteract states of nervousness as well as cardiac tonic due 
to its content in alkaloids with antihypertensive action (Schmid et al., 2012).

Artemisia vulgaris is used in treatment of nervous disorders (McGaw and Jacobus 2010) or reproductive disorders (Viegi et al., 2003).

Giving it as decoction, $20 \mathrm{ml}$ once a day for 10 days, Papaver somniferum (opium poppy) are used to treat nervous system disorders (Pragada et al., 2012).

Plants used in ethnoveterinary medicine to solve reproductive problems, urinary tract disorders in cows

Symphytum officinale L., Hedera helix (common ivy) and Alchemilla vulgaris are administered in mixture with feed in cases of placental retention (Lans et al., 2007).

Alchemilla vulgaris is also used in promotion of oestrus in animals (Viegi. et al., 2003). A similar effect has Senecio vulgaris (ragwort), which, although a toxic plant by its content in senecionine, senecine, senocifidine (El Mahdy et al., 2017), promotes secretion of estrogens and inhibits the secretion of progesterone, prevents and has therapeutic effect in therapy of false gestations (pseudo-gestation) (Laudo and Capasso, 2013).

Malva neglecta (dwarf mallow) similar to Pteridium aquilinum (brakenfern) are plants used for treatment of reproductive disorders (Viegi et al., 2003). Malva sylvestris L. (mallow) has effect on placental elimination and post partum purgative (Pieroni et al., 2004).

Urtica dioica, has utility in treating various reproductive disorders in cows where, 24 hours after calving, decoction obtained from the mixture of one part of nettle peaks, two parts of mallow (Malva sylvestris L.) in addition with bran, has nourishing, astringent and slightly laxative effect (Guarrera, 1987).

The strain and leaves of Urtica dioica are known for their anti-inflammatory effect, used to combat rheumatic pain and inflammation of the urinary tract. Also, can be used like treatment in urinary retention. Roots have diuretic action and decrease the amount of urine in bladder. Grinding 200 grams of roots administered once a day for 3 consecutive days is a treatment used in cases of hematuria (Masood et al., 2015).

Juniperus Sabina (juniper) can be used for curative purposes in treatment of reproductive disorders. Few plants have the property of promote oestrus, and juniper is part of them, but let's not forget about corn (Zea mays), whole plant and grain (Viegi et al, 2003). Juniperus sabina can cause uterine contractions and placenta elimination (Bartha et al., 2015).

Also, decoction of Chelidonium majus can be administered to cows for removal of the placenta (Vlková et al., 2015).

Hedera helix, (ivy) by its content in saponins, chlorogenic and caffeic acid, hederacoside, flavonoids, glycosides, is administered in some parts of Italy to cows after suffering postpartum disorders in form of infusion of leaves, and in other areas, are administered in feed to facilitate the calving (Bullita et al., 2007; Viegi et al., 2003).

Mentha pulegium (mint) has tonic effect on uterus. Both plants, ivy and mint are also beneficial in eliminating problems caused by placental retention (Laudo and Capasso, 2013).

Aerial parts of Capsella bursa-pastoris (shepherd's purse) by numerous active compounds: tannin, tyramine, alkaloids, saponins (Viegi et al., 2003), administered as decoction is indicated in pregnant cows against hemorrhages, but also in treating other reproductive disorders (Laudo and Capasso, 2013).

The whole plant, milled or consumed as such, maintains the health of the udder during the calves suckling period (Martínez and Luján 2011).

To prevent abortion in cows, the leaves of Fragaria L. (strawberry) can be used as tea (Laudo and Capasso, 2013).

Leaves or leaf-bearing stems of Ipomea aquatica (water spinach) given once daily for 15 days, combat the symptoms of hematuria (Satapathy, 2010, Taranisen and Nirlipta, 2016).

\section{Plants used for treatment of mastitis}

Mastitis can be treated with plants: Achillea millefolium L (yarrow)., Salix alba L. (white willow).Taraxacum officinale (dandelion), Zea mays (corn), Symphytum officinale L (comfrey), are plants used to treat edema at udder level (Blanco et al., 1999).

Decoction obtained from leaves of Malva sylvestris L. (mallow), is applied in form of compresses in treatment of mastitis (Uncini Mangenelli et al., 2001).

Atropa Belladonna although it contains toxic alkaloids such as: atropine, scopolamine, hyosciamine, beladonine and nicotine (El Mahdy et al., 2017), it is used to treat systemic symptoms, localized fever of a reddened and painful tissue, of 
Table.1 Species of plants and their healing action

\begin{tabular}{|c|c|c|c|}
\hline $\begin{array}{c}\text { Plants } \\
\text { Latin name }\end{array}$ & $\begin{array}{c}\text { Plants } \\
\text { English name } \\
\end{array}$ & Used for: & Autors \\
\hline $\begin{array}{l}\text { Achillea } \\
\text { millefolium }\end{array}$ & yarrow & $\begin{array}{l}\text { Wounds healing,antiseptic, anti-inflammatory action; } \\
\text { mastitis }\end{array}$ & $\begin{array}{c}\text { Uncini Mangenelli et al., 2001; } \\
\text { Davidović et al, 2012; Blanco et al., } \\
1999\end{array}$ \\
\hline $\begin{array}{l}\text { Aconitum } \\
\text { napellus L }\end{array}$ & queen of poisons & $\begin{array}{l}\text { transport fever, acute changes, stress; antiparasitic } \\
\text { and repellent; eliminate nervous signs in ketosis }\end{array}$ & $\begin{array}{c}\text { McCrory, 2012; } \\
\text { Viegi et al., } 2003 \\
\text { Macleod, } 1981 \\
\end{array}$ \\
\hline $\begin{array}{l}\text { Althaea } \\
\text { officinalis }\end{array}$ & marsh mallow & $\begin{array}{l}\text { digestive disorder: colic, tympanism, reactivation } \\
\text { of rumination, diarrhea and constipation; urinary } \\
\text { disorders, chronic cough; anti-inflammatory effect }\end{array}$ & $\begin{array}{l}\text { Uncini Mangenelli et al., 2001, Quave } \\
\text { et al., } 2012\end{array}$ \\
\hline $\begin{array}{l}\text { Amaranthus } \\
\text { viridis }\end{array}$ & green amaranth & const & Shah et al., 2012 \\
\hline Arnica montana & arnica & $\begin{array}{l}\text { physical trauma at skin level; fever, heart/circulatory, } \\
\text { respiratory tract disorders }\end{array}$ & Chlodwig, 2015 \\
\hline $\begin{array}{l}\text { Artemisia } \\
\text { vulgaris }\end{array}$ & wormwood & $\begin{array}{l}\text { Anthelmintic, repellent action on flies; } \\
\text { gastrointestinal disorders ; combat diarrhea; } \\
\text { stimulates the secretion of digestive enzymes, } \\
\text { disorders of bile secretion; nervous disorders; } \\
\text { reproductive disorders }\end{array}$ & $\begin{array}{c}\text { Severino and Ambrosio, 2012; } \\
\text { Waller et al., 2001; Mayer, 2014; } \\
\text { Quave et al., 2012; Bischoff et al., } \\
\text { 2016; McGaw and Jacobus 2010; } \\
\text { Viegi et al., } 2003\end{array}$ \\
\hline $\begin{array}{c}\text { Atropa } \\
\text { Belladonna }\end{array}$ & & Mastitis; pains & McCrory, 2012; Kumari et al., 2009 \\
\hline $\begin{array}{l}\text { Calendula } \\
\text { officinalis }\end{array}$ & marigold & $\begin{array}{l}\text { skin disorders; antiparasitic and repellent; } \\
\text { bactericidal action; gastritis, gastric ulcer and } \\
\text { duodenal ulcer, colitis, enterocolitis }\end{array}$ & $\frac{\text { www.sadovod-ogorodnik.ru; Viegi et }}{\text { al., 2003; }}$ \\
\hline $\begin{array}{l}\text { Capsella bursa- } \\
\text { pastoris }\end{array}$ & sl & $\begin{array}{l}\text { reproductive disorders, hemorrhages, cicatrisation, } \\
\text { maintain healthy udder }\end{array}$ & $\begin{array}{l}\text { Laudo and Capasso, 2013; Lans et } \\
\text { al., 2007; Martínez and Luján } 2011\end{array}$ \\
\hline $\begin{array}{l}\text { Chelidonium } \\
\text { majus }\end{array}$ & greater celandine & $\begin{array}{l}\text { Skin lesion, combating scabies , anthelmintic; } \\
\text { removal of the placenta, bloating, antidiarrheal }\end{array}$ & $\begin{array}{c}\text { Viegi et al., 2003; Vlková et al., 2015; } \\
\text { Blanco et al., } 1999\end{array}$ \\
\hline $\begin{array}{l}\text { Chenopodium } \\
\text { album }\end{array}$ & lamb's quarters & wound healing & Akash et al., 2014 \\
\hline $\begin{array}{l}\text { Cichorium } \\
\text { intybus }\end{array}$ & chicory & anthelmintics & Abo-EL-Sooud, 2018 \\
\hline $\begin{array}{l}\text { Colchicum } \\
\text { autumnale }\end{array}$ & Autumn crocus & tympanism;external antiparasitic & Macleod, 1981; Viegi et al., 2003 \\
\hline $\begin{array}{c}\text { Conium } \\
\text { maculatum }\end{array}$ & hemlock & Wounds healing, abscesses & Viegi et al., 2003 \\
\hline $\begin{array}{l}\text { Convallaria } \\
\text { majalis }\end{array}$ & lily of the valley & cardiac failure; diuretic & $\begin{array}{l}\frac{\text { Laudo and Capasso, 2013; ( } \underline{\mathrm{http}: / /}}{\text { poisonousplants.ansci.cornell.edu/, }} \\
2015\end{array}$ \\
\hline $\begin{array}{l}\text { Convolvulus } \\
\text { arvensis }\end{array}$ & $\begin{array}{l}\text { European } \\
\text { bindweed }\end{array}$ & Constipation & Akash et al., 2014 \\
\hline Cuscuta reflexa & giant dodder & $\begin{array}{c}\text { ectoparasites removal, foot-and-mouth disease } \\
\text { treatment }\end{array}$ & $\begin{array}{l}\text { Akash et al., 2016; Malla and Chhetri, } \\
2012\end{array}$ \\
\hline $\begin{array}{l}\text { Cynodon } \\
\text { dactylon }\end{array}$ & bermuda grass & $\begin{array}{l}\text { Oliguria; internal lesions ; hematuria ; anthelmintic; } \\
\text { mastitis; increasing milk production and milk quality; } \\
\text { conjunctivitis; wounds healing }\end{array}$ & $\begin{array}{l}\text { Masood et al., 2015; Venkata } \text { et al., } \\
\text { 2016; Verma, 2014; Nagayya et al., } \\
2017 \\
\end{array}$ \\
\hline $\begin{array}{c}\text { Datura } \\
\text { stramonium }\end{array}$ & thorn apple & $\begin{array}{l}\text { antiparasitic, repellent; control seizures in ketosis; } \\
\text { pain relieve }\end{array}$ & $\begin{array}{c}\text { Pragada et al., 2012; Macleod, 1981; } \\
\text { Kumari et al., } 2009\end{array}$ \\
\hline Digitalis lanata & woolly foxglove & heart disease & Tikofsky, 2013 \\
\hline $\begin{array}{c}\text { Digitalis } \\
\text { purpureea }\end{array}$ & common foxglove & burns & Tikofsky, 2013, Kumari et al. 2012 \\
\hline $\begin{array}{l}\text { Equisetum } \\
\text { arvense }\end{array}$ & horsetail & $\begin{array}{c}\text { maintain the mineral balance } \\
\text { immunostimulatory action; gastrointestinal } \\
\text { disorders; urinary problems }\end{array}$ & $\begin{array}{l}\text { Www.bionaturesanteanimale.fr; } \\
\text { Davidović et al., 2012; Viegi et al., } \\
\text { 2003; }\end{array}$ \\
\hline $\begin{array}{l}\text { Eryngium } \\
\text { planum } \mathrm{L}\end{array}$ & sea holly & mastitis & Bartha et al., 2015 \\
\hline $\begin{array}{l}\text { Euphorbia } \\
\text { lathyris }\end{array}$ & caperspurge & $\begin{array}{l}\text { gastrointestinal disorders, purgative; repellent for } \\
\text { mice, }\end{array}$ & $\begin{array}{l}\text { Viegi et al., 2003; Uncini Mangenelli } \\
\text { et al., } 2001\end{array}$ \\
\hline
\end{tabular}




\begin{tabular}{|c|c|c|c|}
\hline $\begin{array}{l}\text { Fagopyrum } \\
\text { esculentum }\end{array}$ & buckwheat & $\begin{array}{c}\text { diuretic; anemia; liver disorder; foot-and-mouth } \\
\text { disease }\end{array}$ & $\begin{array}{l}\text { Suroowan et al., 2017; Akash et al., } \\
\text { 2014; Masood et al., 2015; Sharma } \\
\text { et al., 2012 }\end{array}$ \\
\hline Fragaria L. & awberry & prevent abortion & Laudo and Capasso, 2013 \\
\hline \multirow[b]{2}{*}{ Fraxinus ornus } & & Diarrhea, ectoparasites & Mayer, 2014 \\
\hline & $\begin{array}{l}\text { Manna Ash } \\
\text { +eldeberry }\end{array}$ & gastrointestinal inflammation & Uncini Mangenelli et al., 2001 \\
\hline $\begin{array}{c}\text { Gentiana } \\
\text { asclepiadea } \mathrm{L}\end{array}$ & gentian willow & $\begin{array}{l}\text { Inflammation, pain relieve, digestive disorders, } \\
\text { mastitis }\end{array}$ & $\begin{array}{l}\text { Bartha et al., 2015; Uncini } \\
\text { Mangenelli } \text { et al., } 2001\end{array}$ \\
\hline Hedera helix & ivy & $\begin{array}{l}\text { snake bites; placental retention; postpartum } \\
\text { disorders; facilitating calving }\end{array}$ & $\begin{array}{l}\text { Viegi and Ghedira, 2014; Lans et al., } \\
\text { 2007, Bullita et al., 2007; Viegi et al., } \\
\text { 2003 }\end{array}$ \\
\hline $\begin{array}{l}\text { Helleborus } \\
\text { purpurascens, } \\
\text { H. bocconei,H. } \\
\quad \text { foetidus }\end{array}$ & hellebore & $\begin{array}{l}\text { respiratory conditions, inflammation; bronchitis } \\
\text {;pneumonia; cold and coughing; immunostimulatory } \\
\text { effect, bloating,tympanism; external antiparasitic; } \\
\text { treatment of purulent abscesses; prevent acidosis }\end{array}$ & $\begin{array}{c}\text { Maior, et al, 2013; Vlková et al., } \\
\text { 2015;Bartha et al., 2015; Uncini } \\
\text { Mangenelli et al., 2001; Davidović et } \\
\text { al., 2012; www.sadovod-ogorodnik. } \\
\text { ru/; Uncini Mangenelli et al., 2001; } \\
\text { Groot et al., } 2001\end{array}$ \\
\hline $\begin{array}{l}\text { Hyoscyamus } \\
\text { niger }\end{array}$ & $\begin{array}{c}\text { stinking } \\
\text { nightshade }\end{array}$ & lameness, pain relief & $\begin{array}{c}\text { Viegi et al., 2003; Suroowan et al., } \\
2017 \\
\end{array}$ \\
\hline $\begin{array}{l}\text { Hypericum } \\
\text { perforatum } \mathrm{L}\end{array}$ & St John's-wort & $\begin{array}{l}\text { stomach, intestinal, bladder inflammation } \\
\text { swelling, treatment against painful join }\end{array}$ & $\begin{array}{c}\text { www.sadovod-ogorodnik.ru ; Jarić } \\
\text { et al., 2007; Uncini Mangenelli et al., } \\
2001 \\
\end{array}$ \\
\hline Ipomea aquatica & water spinach & hematuria & $\begin{array}{l}\text { Satapathy, 2010; Taranisen and } \\
\text { Nirlipta, } 2016\end{array}$ \\
\hline Juglans nigra & black walnut & testinal parasit & Tikofsky, 2013 \\
\hline $\begin{array}{l}\text { Juniperus } \\
\text { communis }\end{array}$ & $\begin{array}{c}\text { juniper } \\
\text { juniper+wine } \\
\text { juniper +urine+ } \\
\text { turpentine }\end{array}$ & $\begin{array}{c}\text { infestation with ecto- endoparasites, liverworms; } \\
\text { strengthening the joints } \\
\text { respiratory diseases }\end{array}$ & $\begin{array}{l}\text { Lans et al., 2007; Viegi et al, 2003; } \\
\text { Uncini Mangenelli et al., 2001; } \\
\text { Bartha et al., } 2015\end{array}$ \\
\hline Juniperus sabina & juniper & reproductive disorders; placenta elimination & Bartha et al., 2015; \\
\hline $\begin{array}{c}\text { Linum } \\
\text { Usitatissimum L }\end{array}$ & $\begin{array}{c}\text { flaxseeds }+ \\
\text { mallow }\end{array}$ & $\begin{array}{l}\text { digestive disorders ; relieves spasmodic } \\
\text { manifestations or convulsions; flatulence } \\
\text { reactivation of the rumination }\end{array}$ & $\begin{array}{l}\text { Viegi et al., 2003; Al Mamun et al., } \\
\text { 2015; } \\
\text { González et al., } 2011 \\
\end{array}$ \\
\hline Lupinu & $\begin{array}{l}\text { white lupine } \\
\text { white lupine+ } \\
\text { bean beans }\end{array}$ & $\begin{array}{c}\text { ectoparasites, } \\
\text { galactophore action }\end{array}$ & $\begin{array}{l}\text { Tikofsky, 2013; Bischoff et al., 2016; } \\
\text { Di Sanzo et al., } 2013\end{array}$ \\
\hline $\begin{array}{l}\text { Malva sylvestris } \\
\text { L. }\end{array}$ & mallow & $\begin{array}{l}\text { reactivation of rumination, meteorism; placental } \\
\text { elimination and post partum purgative; mastitis, }\end{array}$ & $\begin{array}{l}\text { González et al., 2011; Pieroni } \text { et al., } \\
\qquad 2004 \\
\text { Uncini Mangenelli et al., } 2001 \\
\end{array}$ \\
\hline $\begin{array}{l}\text { Matricaria } \\
\text { chamomilla L }\end{array}$ & nile & $\begin{array}{c}\text { digestive disorders, abdominal pain; induce } \\
\text { changes in bacterial morphology on Bacillus cereus } \\
\text { and Staphylococcus aureus , healing effect, udder } \\
\text { inflammation, , inhibits fermentation processes in the } \\
\text { gut; dyspepsia }\end{array}$ & $\begin{array}{l}\text { Mayer et al., 2014; Abo-El-Sooud, } \\
\text { 2018; www.sadovod-ogorodnik.ru; } \\
\text { Bartha et al., } 2015\end{array}$ \\
\hline Melilotus albus & elilot & indigesti & Kumari et al., 2009 \\
\hline lentha pulegium & nt & place & Laudo and Capasso, 2013 \\
\hline $\begin{array}{l}\text { Mercurialis } \\
\text { annua }\end{array}$ & annual mercury & Purgative, placenta removal & $\begin{array}{l}\text { Viegi et al., 2003; Pieroni et al., 2004; } \\
\text { Uncini Mangenelli et al., } 2001\end{array}$ \\
\hline Morus Nigra L & black mulberry & infected skin & Akash et al., 2016 \\
\hline $\begin{array}{l}\text { Nicotiana } \\
\text { tabacum L. }\end{array}$ & tobacco & $\begin{array}{c}\text { snake bites , fattening; anthelmintic; tick } \\
\text { infestations; myiazis; foot-and-mouth disease, } \\
\text { eczema }\end{array}$ & $\begin{array}{l}\text { Yared et al., 2014; Gakuya et } \\
\text { al., 2011; Sharma et al., 2012; } \\
\text { Suroowan et al., 2017; Farrah, } \\
\text { 2009); Bischoff et al., 2016; } \\
\text { Lakshmi and Narasimharao, 2015; } \\
\text { Venkata et al., 2016; Akash et al., } \\
\text { 2016; Al Mamun et al.,2015; }\end{array}$ \\
\hline $\begin{array}{l}\text { Papaver } \\
\text { omniferum }\end{array}$ & ppy & $\begin{array}{c}\text { nervous system disorders; mastitis and inflammatic } \\
\text { of udder }\end{array}$ & $\begin{array}{l}\text { Pragada et al., 2012; Bartha et al., } \\
2015\end{array}$ \\
\hline
\end{tabular}




\begin{tabular}{|c|c|c|c|}
\hline $\begin{array}{c}\text { Plantago } \\
\text { lanceolata }\end{array}$ & ribwort plantain & Inflammation, pain relieve & Bartha et al., 2015 \\
\hline Plantago major & $\begin{array}{l}\text { Broad leaf } \\
\text { Plantain }\end{array}$ & \multicolumn{2}{|c|}{ Hooves and oral cavity treatment; toothache, fever Shah et al., 2012; Kumari et al., 2012} \\
\hline Prunus persica & peach tree & wounds healing eve problems & Luseba and Tshisikhawe, 2013 \\
\hline Quercus ilex & evergreen oak & \multirow[b]{2}{*}{ diarrhea } & \multirow{2}{*}{$\begin{array}{l}\text { Mayer, 2014, González et al., 2011, } \\
\text { Bartha et al., 2015Bartha et al., } 2015\end{array}$} \\
\hline $\begin{array}{l}\text { Quercus petraea } \\
\text { Matt }\end{array}$ & sessile oak & & \\
\hline $\begin{array}{c}\text { Ricinus } \\
\text { communis L }\end{array}$ & castor bean & $\begin{array}{c}\text { constipation; laxative effect, stimulates intestinal } \\
\text { secretion, dermatophilia, placental retention; wound } \\
\text { healing; hyperthermia }\end{array}$ & $\begin{array}{c}\text { Fitsum and Mekonnen, 2017; van } \\
\text { der Merwe et al., 2010; Zia-Ud-Din } \\
\text { et al., 2010; Malla and Chhetri, 2012; } \\
\text { Akash } \text { et al., } 2014\end{array}$ \\
\hline
\end{tabular}

\section{Rumex acetosella}

L sheep sorrel gastrointestinal disorders, diarrhea

Viegi et al., 2003; Bartha et al.,2015

\begin{tabular}{|c|c|c|c|}
\hline $\begin{array}{c}\text { Rumex crispus } \\
\text { Rumex } \\
\text { obtusifolius L }\end{array}$ & $\begin{array}{l}\text { curly dock } \\
\text { bitter dock }\end{array}$ & diarrhea & $\begin{array}{l}\text { Uncini Mangenelli et al., 2001; } \\
\text { Bartha et al.,2015 }\end{array}$ \\
\hline Sambucus ebulus & dwarf elder & $\begin{array}{l}\text { Purgative, snake bite, treat burned areas, } \\
\text { inflammations, edema, eczema, urticaria }\end{array}$ & $\begin{array}{r}\text { Di Sanzo et al., } 20 \\
\text { al., } 20\end{array}$ \\
\hline Sambucus nigra & black eldeberry & $\begin{array}{l}\text { Wounds healing, infected nails; udder inflammation; } \\
\text { promoter of growth; gastrointestinal disorders, } \\
\text { laxative and purgative }\end{array}$ & $\begin{array}{c}\text { Bullitta et al., 2007; Viegi and } \\
\text { Ghedira , 2014; Matchett, www. } \\
\text { sapork.biz; Mayer et al., } 2014\end{array}$ \\
\hline Senecio vulgaris & ragwort & $\begin{array}{l}\text { snake bites, promotes secretion of estrogens; pseudo- } \\
\text { gestation }\end{array}$ & $\begin{array}{l}\text { Viegi and Ghedira, 2014; Laudo and } \\
\text { Capasso, } 2013\end{array}$ \\
\hline $\begin{array}{l}\text { Silybum } \\
\text { eburneum }\end{array}$ & milk tl & liver disorder, giardia, growth & www.bionaturesanteanimale.fr \\
\hline Solanum nigrum & black nightshade & $\begin{array}{l}\text { gastrointestinal disorders; gastritis; purgative; } \\
\text { flatulence; fever }\end{array}$ & $\begin{array}{l}\text { Suroowan et al., 2017; Pragada } \\
\text { et al., 2012; Venkata et al., 2016; } \\
\text { Gwalwanshi and Bishwas, 2017; } \\
\text { Taranisen and Nirlipta, } 2016\end{array}$ \\
\hline $\begin{array}{l}\text { Symphytum } \\
\text { officinale L }\end{array}$ & Comfrey & $\begin{array}{c}\text { Wounds healing; anti-pruritus and disinfectant of } \\
\text { the skin, acute mastitis, lesions , edema of the udder, } \\
\text { ketosis }\end{array}$ & $\begin{array}{l}\text { Laudo and Capasso, 2013; Lans et } \\
\text { al., 2007; Blanco et al., } 1999\end{array}$ \\
\hline $\begin{array}{l}\text { Tanacetum } \\
\text { vulgare }\end{array}$ & $\operatorname{tansy}$ & $\begin{array}{l}\text { wounds treating, ulcers, anthelmintics, intensifies } \\
\text { intestinal peristalsis, enterocolitis (calves) }\end{array}$ & $\begin{array}{l}\text { Waller et al., 2001; www.sadovod- } \\
\text { ogorodnik.ru }\end{array}$ \\
\hline Thymus vulgaris & thyme & diarrhea, stomach pain & Masood et al., 2015 \\
\hline Urtica dioica & stinging nettle & $\begin{array}{l}\text { antihelminthic, wound healing; galactogen; } \\
\text { functional food, natural calcium intake; combats zinc } \\
\text { deficiency, diarrhea, anti- asthenic and antianemic } \\
\text { effect; reproductive disorders; rheumatic pain } \\
\text { inflammation of the urinary tract; diuretic, }\end{array}$ & $\begin{array}{l}\text { Laudo and Capasso, 2013; Lans et al, } \\
\text { 2007; Di Sanzo et al., 2013; McGaw } \\
\text { and Jacobus, 2010; Masood et al., } \\
\text { 2015; Guarrera, } 1987\end{array}$ \\
\hline $\begin{array}{l}\text { Veratrum album } \\
\mathrm{L}\end{array}$ & white hellebore & $\begin{array}{c}\text { wolf bite, lice removal; mites; diarrhea; emetic; } \\
\text { counteract states of nervousness, antihypertensive } \\
\text { action }\end{array}$ & $\begin{array}{c}\text { Davidović et al., 2012; Gub, 2005; } \\
\text { Lans et al., 2007; Di Sanzo et al., } \\
\text { 2013; Bartha et al., 2015; Schmid et } \\
\text { al., } 2012 \\
\end{array}$ \\
\hline
\end{tabular}

coughing, treating gastrointestinal disorder,

Viburnum spp viburnum diarrhea; relax intestinal muscles, vitaminizing, tonic, ww.sadovod-ogorodnik.ru diaphoretic

the quarters of udder affected by acute mastitis (McCrory, 2012). Leaves prepared as ointment, relieve "killing pains" in cows (Kumari et al., 2009).

Seeds of Papaver somniferum (opium poppy) administered as feed are used in cases of mastitis and inflammation of udder (Bartha et al., 2015).

In Covasna county (Transylvania, Romania), Eryngium planum L (sea holly), with its antiinflammatory properties is used by preparing a tea with which, is wash the inflamed udder caused by mastitis (Bartha et al., 2015).

Leaves of Plantago lanceolata (ribwort plantain), rich in active compounds such as: iridoid, called aucubine, flavonoids, mucilages, volatile oils and antibiotic substances, phytonocides, phytoquinone, carotenoids, minerals (Rotaru, www.csid.ro/) are used to treat inflammation and reduce pain (Bartha et al., 2015). 


\section{Plants used in ethnoveterinary medicine for relieving pain in cows}

Pain in cow, can be removed by using ointment, which has like ingredient, leaves of thorn apple (Datura stramonium) (Kumari et al., 2009).

Leaves, flowers of boneset (Eupatorium perfoliatum), diminish bone pain and fever in cows, have immunostimulant effect (Tikofsky, 2013).

Fruits and small branches of Juniperus communis $\mathrm{L}$ (juniper) in form of decoction prepared with wine, have role of strengthening the joints, applied in form of compression on the tired joints of animals (Uncini Mangenelli et al., 2001).

Hypericum perforatum L. (St John's-wort), has analgesic and healing effect of wounds applied in form of mixture (olive oil and macerated plant) with which the painful joints are massaged or is applied to the lesions. After the same author, Salix alba L. (white willow) helps relieve pain, inflammation, and leaf branches and the bark of the tree given in feed, improves the rumination of cows.

\section{Conclusion}

The plants existing in spontaneous flora of Romanian pastures can be used by the farmers in large numbers as treatments for healing some disorders at cows. Most of the plants have complex action, but most can be used in treatment of gastrointestinal disorder, mastitis, wound healing, antiparasitic. Some diseases can be treated with the help of plants, which represents almost the only way for farmers registered in the organic farming system to keep their livestock healthy.

\section{References}

1. Abo-El-Sooud K (2018). Ethnoveterinary perspectives and promising future, International Journal of Veterinary Science and Medicine, 6:1-7

2. Akash T, Adnan M, Mussarat S (2016). Use of ethnoveterinary medicines by the people living near pakafghan border region, Slov Vet Res, 53(3), 119-30, UDC 61 5.89:636.09:616:61:001.5(549.1)

3. Akash T, Mussarat S, Adnan M, AbdElsalam NM, Ullah R, Khan, A.L. (2014). Ethnoveterinary Study of medicinal plants in a tribal society of Sulaiman Range. The Scientific World Journal pg.1-10, http://dx.doi.org/

4. Al Mamun A, Tumpa SI, Hossain MdI, IshikaT (2015) Plant resources used for traditional ethnoveterinary phytotherapy in Jessore District, Bangladesh, Journal of Pharmacognosy and Phytochemistry, 3 (6), 260-267
5. Bartha SG, Quave CL, Balogh L, Papp N (2015) Ethnoveterinary practices of Covasna County,Transylvania, Romania. J. of Ethnobiology and Ethnomedicine,vol.11:35, 1-22, DOI 10.1186/s13002-015-0020-8

6. Bischoff $\mathrm{T}$, Vogl CR, Ivemeyer S, Klarer F, Meier B, Hamburger M (2016) Plant and natural product based homemade remedies manufactured and used by farmers of six central Swiss cantons to treat livestock. Livestock science,189,110-125

7. Blanco E, Macia MJ, Morales R (1999) Medicinal and veterinary plants of El Caurel (Galicia, northwest Spain), Journal of Ethnopharmacology, 65, 113-124

8. Bourke CA, White JG (2004) Reassessment of the toxicity of Hypericum perforatum (St John's wort) for cattle. Aust Vet J., . 82 (11), 707-710

9. Bullitta S, Piluzza G, Viegi L (2007) Plant resources used for traditional ethnoveterinary phytotherapy in Sardinia (Italy), Genet Resour Crop Evol, 54, 1447-1464

10. Celik I, Tuluce Y (2007). Elevation protective role of Camellia sinensis and Urtica dioica infusion against trichloroacetic acid-exposed in rats, Phytotherapy reaserch, 11, 1039-1044

11. Chaney M (2015). Livestock - Toxic Plants http://www. piercecountycd.org/

12. Chlodwig F (2015). Herbal medicinal product and feed additives in veterinary medicine and animal nutrition. Le universita clinical features and circumstances of exposure. Clin Toxicol, 49, 671-680.

13. Davidović V, Joksimović TM, Stojanović B, Relić (2012). Plant usage in protecting the farm animal health. Biotechnology in Animal Husbandry, 28 (1), 87-98

14. Di Sanzo P, De Martino L,Mancini E, De Feo V (2013). Medicinal and useful plants in the tradition of Rotonda, Pollino National Park, Southern Italy, Journal of Ethnobiology and Ethnomedicine, 9 (1), 1-9

15. Dilpreet K, Jaiswal K, Mishra S (2015). Ethnoveterinary practices in India: A Review, European journal of pharmaceutical and medical research, 2(7), 139-143

16. El Mahdy C, Popescu S, Borda C (2017). Plants that can be Poisonous for Cows. A Review. Bulletin UASVM Animal Science and Biotechnologies, 74(2),69-83

17. Farrah D (2009).Documentation of ethno-veterinary practices in urban and peri- urban areas of Faisalabad (Pakistan), PhD tesis, Faculty Of Veterinary Science University Of Agriculture, Faisalabad Pakistan, 1-269

18. Fitsum D, Mekonnen A (2017) Ethnoveterinary Medicine Practices in Ethiopia: Review. Advances in Biological Researchm, 11 (3), 154-160

19. Gaillard Y, Gilbert P (2001). LC-EI-MS determination of veratridine and cevadine in two fatal cases of Veratrum album poisoning. J.of Analytical Toxicology, 25, 481- 485

20. Gakuya DW, Mbaria JM, Kiama SG, Gathumbi PK, Mathiu M, Nguta JM (2011) Ethnoveterinary Medicine: The prospects of integrating medicinal plant products in Veterinary Medicine in Kenya.The Kenya Veterinarian. A Journal of the Kenya Veterinary Association, 35 (2),1-11

21. Gilotta I, Brvar M (2010). Accidental poisoning with Veratrum album mistaken for wild garlic 
(Allium ursinum). Clin Toxicol (Phila) 48, 949-952. doi:10.3109/15563650.2010.5

22. González JA, García-Barriuso M, Amich F (2011) Ethnoveterinary medicine in the Arribes del Duero, western Spain, Vet Res Commun, 3, 283-310

23. Groot M, Kleijer-Ligtenberg G, Van Asseldonk T, Hansma H (2011) Koe Natuurlijk BioKennis, BAS number BO-04002-002.029 RIKILT-Wageningen UR

24. Gub J (2005). Népi növényismeret a Nagy-Homoród mentén. In: Zsigmond G, editor. Növények a folklórban. Bucharest: A Magyar Köztársaság Kulturális Intézete, 148-162

25. Gwalwanshi DR, Bishwas AJ (2017). Documentation of ethnoveterinary medicinal flora of Balaghat District, Madhya Pradesh, India. Int. J. Res. Ayurveda Pharm., 8 (2), 279-284

26. Jarić S, Popović Z, Mačukanović-Jocić M, Djurdjević L, Mijatović M, Karadžić B, Mitrović M, Pavlović P (2007). An ethnobotanical study on the usage of wild medicinal herbs from Kopaonik Mountain (Central Serbia). J. of Ethnopharmacology, 111, 160-175.

27. Kohli RN (2015). Ethno-veterinary Medicine: A Concept for Sustainable Livestock Production), Royal Offset Printers, A-89/1, Naraina Industrial Area, Phase-I, New Delhi-110 028

28. Krishna L, Swarup D, Patra DRC (2005). An overview of prospects of ethno-veterinary medicine in India. Indian. J. Anim. Sci., 75, 1481-1491.

29. Kumari P, Singh BK, Joshi GC, Tewari LM (2009). Veterinary Ethnomedicinal Plants in Uttarakhand Himalayan Region, India. Ethnobotanical Leaflets, 13, 1312-27

30. Lakshmi N, Narasimharao GM (2015). Plants used in ethnoveterinary medicine by tribals of Visakhapatnam and Vizianagarm Districts, Andhra Pradesh, India. Int. International Journal Pure App. Biosci., 3 (2), 432-439

31. Lans C, Turner N, Khan T, Brauer G, Boepple W (2007). Ethnoveterinary medicines used for ruminants in British Columbia, Canada, J Ethnobiol Ethnomed; 3 (11), 1-22, doi: 10.1186/1746-4269-3-11

32. Laudo M, Capasso R (2013). Useful plants for animal therapy. A alternative medicine. www.oapublishinglondon. com/article/327

33. Luseba D and Tshisikhawe MP (2013). Medicinal plants used in the treatment of livestock diseases in Vhembe region, Limpopo province, South Africa. Journal of Medicinal Plants Research Vol. 7(10), 593-601, DOI:10.5897/JMPR012.1213

34. Macleod G (1981). The Treatment of Cattle by Homoeopathy, www.randomhouse.co.uk

35. Malla B, Chhetri RB (2012). Ethnoveterinary practices of some plant species by ethnic people of Parbat district, Nepal, Kathmandu University Journal of Science, Engineering And Technology, 8 (I), 44-50, https://doi. org/10.3126/kuset.v8i1.6042

36. Martínez GJ, Luján MC (2011). Medicinal plants used for traditional veterinary in the Sierras de Córdoba (Argentina): An ethnobotanical comparison with human medicinal uses. Journal of Ethnobiology and Ethnomedicine, pg 7-25

37. Masood KA, Shafkat AG, Pranav K, Bhadwal MS, Rizwan JR (2015). Etno-veterinary practices used for the treatment of animal diseases in Doda district , Jammu and Khasmir, Indian Journal of traditional knowledge, 14, 306-312

38. Matchett JR. A Review of the Use of Plants as EthnoVeterinary Medical Replacements for Antibiotic Growth Promoters, https://www.sapork.biz/

39. Mayer M (2014). Complementary and alternative medicine on italian organic farms and ethnoveterinary as a possible strategy for disease treatment, https://mariamayer.it/.../ Mayer-PhD-thesis

40. Mayer M, Vogl CR, Amorena A, Hamburger M, Walkenhorst M (2014). Treatment of organic livestock with medicinal plants: A systematic review of European ethnoveterinary research, Forsch Komplementmed, 21, 375-386

41. Mayer M, Zbinden M, Vogl CR, Ivemeyer S, Meier B, Amorena M, Maeschli A, Hamburger M,Walkenhorst M (2017). Swiss ethnoveterinary knowledge on medicinal plants - a within-country comparison of Italian speaking regions with north-western German speaking regions, Journal of Ethnobiology and Ethnomedicine, 13:1, DOI 10.1186/s13002-016-0106-y

42. McCrory L (2012). Homeopathy For Livestock http:// www.nofamass.org/

43. McGaw LJ, Jacobus N, Eloff JN (2010). Chapter 1.Methods for Evaluating Efficacy of Ethnoveterinary Medicinal Plants, din Ethnoveterinary Botanical Medicine Herbal Medicines for Animal Health, CRC Press, https://doi. org/10.1201/EBK1420045604-c1

44. Mooventhan P, Manimaran A, Kumar KS, Selvan AS, Prakash MA (2016). Indigenous ethnoveterinary medicinal practices for management of mastitis in dairy cattle, Indian J. Anim. Res., 50 (1),137-139

45. Moreki JC,Tshireletso K, Okoli IC (2012). Potential use of ethnoveterinary medicine for retained placenta in cattle in mogonono, Botswana J. Anim. Prod. Adv., 2(6), 303-309

46. Nagayya S, Gotruvalli M, Kumar P (2017). Utilization of ethno-veterinary medicinal plants in Hassan district of Karnataka, India, International Journal of Pharmacy and Pharmaceutical Sciences, 9 (4), 107-112

47. Pieroni A, Howard P, Volpato G, Santoro RF (2004). Natural remedies and nutraceuticals used in etnoveterinary practices in inland southern Italy, veterinary research communication, 28, 55-80

48. Poutaraud A, Michelot-Antalik A, Plantureux S (2017). Grasslands: A Source of Secondary Metabolites for Livestock Health, J. Agric. Food Chem, 65 (31), 6535-6553.

49. Pragada PM, Geddada M, Narasimha R (2012). Ethnoveterinary medicinal practices in tribal regions of Andhra Pradesh, India, Bangladesh J. Plant Taxon., 19 (1), 7-16

50. Quave CL, Pardo-de-Santayana M, Pieroni A (2012). Medical ethnobotany in Europe: from field ethnography to a more culturally sensitive evidence-based CAM?, Hindawi Publishing Corporation Evidence-Based Complementary and Alternative Medicine, 2012, Article ID 156846, 1-17 
51. Rikilt GM, Kleijer-Ligtenberg G, Tedje van Asseldonk IEZ, KoeNatuurlijk HH (2011). BioKennis.BAS number B0-04002-002.029.mRIKILT-Wageningen UR

52. Rotaru, P. Pătlăgină (Plantago lanceolata) - Beneficii şi proprietăţi http://www.csid.ro/

53. Satapathy KB (2010). Ethnoveterinary practices in Jajpur district of Orissa, Indian Journal Of Traditional Knowledge, 9 (2), 338-343

54. Schmid K, Ivemeye S, Vogl C, Klarer F, Meier B, Hamburger M, Walkenhorst M (2012). Traditional Use of Herbal Remedies in Livestock by Farmers in 3 Swiss Cantons (Aargau, Zurich, Schaffhausen) Forsch Komplementmed, $19,125-136$

55. Selvaraju A, Ayyanar M, Rathinakumar SS, Sekar T (2011) Plants used in ethno-veterinary medicine by malayali tribal in Salem district of Tamil Nadu, India. Medicinal Plants, 3(3): pp.1-6

56. Severino L, Ambrosio L (2012). Medicinal Plants: Biodiversity and Drugs: Chapter 12 .Herbal Drugs Used for Domestic Animals, pp. 334- 354, CRC Press, Taylor \& Francis Group, Boca Raton

57. Shah GM, Ahmad M, Arshad M, Khan MA, Zafar M, Sultana $S$ (2012) Ethno-phyto-veterinary medicines in northern Pakistan, The Journal of Animal \& Plant Sciences, 22(3), 791-797

58. Sharma, T.P., Sabita, D., Borthakur, S. K. (2012) Documentation of Ethno-veterinary practices in Sikkim, India, Pleione 6(2), 353 - 358

59. Sri Balaji N, Vikrama Chakravarthi P (2010). Ethnoveterinary practices in India - A Review. Vet. World. 3, 549-551.

60. Stevens M (2003). Plant guide-common elderberry Sambucus nigra L. ssp. canadensis (L.) R. Bolli http:// plants.usda.gov

61. Suroowan S, Javeed F, Mushtaq A, Zafar M, Mehwish JN, Sadaf K, Javed A, Mahomoodally MF (2017). Ethnoveterinary health management practices using medicinal plants in South Asia - A review. Vet Res Commun ,41, 147-168

62. Taranisen P, Nirlipta M (2016). Indigenous knowledge on animal health care practices in Kendrapara district of Odisha, India, International Letters of Natural Sciences, $53,10-27$

63. Tikofsky L (2013).Organic Dairy Herd Health: Alternative and Complementary Treatment and Medicines http:// articles.extension.org/

64. Uncini Mangenelli RE, Camangi F, Tomei PE (2001). Curing animals with plants: traditional usage in Tuscany (Italy), journal od Etnopharmacology, 78, 171-191

65. Van der Merwe D, Swan GE, Botha C J (2010). Use of ethnoveterinary medicinal plants in cattle by Setswanaspeaking people in the Madikwe area of the North West, Province of South Africa, http://hdl.handle.net/

66. Venkata K, Rami R, Nagalakshmi Devamma M, Prayaga PM (2016). Ethnoveterinary medicinal practices in
Rayala Seema regions of Andhra Pradesh, India, European Journal of Environmental Ecology, 3(1), 7-20.

67. Verma RK (2014). An ethnobotanical study of plants used for the treatment of livestock diseases in Tikamgarh District of Bundelkhand, Central India, Asian Pac J Trop Biomed, 4(Suppl 1), S460-S467

68. Verma S, Singh SP (2008). Current and future status of herbal medicines, Veterinary World, 1(11), 347-350

69. Viegi L, Ghedira K (2014). Preliminary Study of Plants Used in ethnoveterinary medicine in Tunisia and in Italy, Afr J Tradit Complement Altern Med. 11(3), 189-199.

70. Viegi L, Pieroni A, Guarrera PM, Vangelisti R (2003). A review of plants used in folk veterinary medicine in Italy as basis for a databank Journal of Ethnopharmacology 89, 221-244

71. Vlková M, Kubátová E, Šlechta P, Polesný Z (2015). Traditional use of plants by the disappearing Czech diaspora in Romanian Banat, Scientia agriculturae bohemica, 46, (2), 49-56

72. Waller PJ, Bernes G, Thamsborg SM, Sukura A, Richter SH, Ingebrigtsen K, Höglund J (2001). Plants as De-Worming Agents of Livestock in the Nordic Countries: Historical Perspective, Popular Beliefs and Prospects for the Future, Acta vet. Scand, 42, 31-44

73. Wanzala W, Zessin KH, Kyule NM, Baumann MPO, Mathias E, Hassanali A (2005). Ethnoveterinary medicine: a critical review of its evolution, perception, understanding and the way forward, Livestock Research for Rural Development 17 (11), http://www.lrrd.org/lrrd17/11/wanz17119. htm

74. Wedson MSS, Barboza RRD, Rocha MSP, Alves RRN, Mourão JS (2012). Animal-based medicines used in ethnoveterinary practices in the semi-arid region of Northeastern Brazil, Anais da Academia Brasileira de Ciências 84 (3), 669-678

75. Wink M (2009). Mode of action and toxicology of plant toxins and poisonous plants, Mitt. Julius Kühn-Inst: 93112

76. Yared Y, Demissew BH, Wubeante YA (2014). Ethnoveterinary medicines in four districts of Jimma zone, Ethiopia: cross sectional survey for plant species and mode of use. BMC Veterinary Research, 10:76, 1-12

77. Zia-Ud-Din S, Iqbal Z, Khan MN, Jonsson NN, Siddique M (2010). Documentation of ethnoveterinary practices used for treatment of different ailments in a selected hilly area of Pakistan, International Journal of Agriculture \& Biology, 12, 353-358

78. XXX www.bionaturesanteanimale.fr/

79. X X X www.infuziedesanatate.ro/

80. X X X www.sadovod-ogorodnik.ru/

81. X X X www.romedic.ro/

82. http://poisonousplants.ansci.cornell.edu/, 2015 